\title{
Effect of Treasury Risk Management on Financial Performance of Kenyan Deposit Taking Saccos; A Case of Nakuru County
}

\author{
Alice chamwana ${ }^{1}$, Abel G. Anyieni ${ }^{2}$ \\ ${ }^{1}$ Accounting \& Finance Department, Kenyatta University (Nakuru Campus), P.O. Box 21677, Kenya \\ ${ }^{2}$ Lecturer School of Business, Kenyatta University (Nakuru Campus), P.O. Box 21677-00100 GPO, Nairobi, \\ Kenya
}

\begin{abstract}
Treasury management has been and still is a global concern not only in formal corporate world but also in informal financial sector. In Financial institutions, treasury management is about the aspect of risk management by measuring it, controlling it, diversifying it and hedging it. Risk taking is the heart of every financial institution and it is the conscious engagement in risk that constitutes the economic value of financial intermediation. Treasury risk management therefore refers to the process of identifying a suitable trade-off between risks and return in order to maximize the existing opportunities in a society's operational environment. The advent of regulation in the SACCO sector and the development of commercially autonomous member-based cooperative organizations which are democratically and professionally managed, self-controlled and selfreliant business enterprises means that Cooperative societies can now compete with other business enterprises for the financial business market share. The researcher therefore sought to establish whether licensed deposit taking SACCO societies have adopted the practice of treasury risk management and how this has affected their financial performance. To establish this, the researcher adopted a survey study since it describes in-depth the nature of the phenomenon and examines actions as they happen rather than manipulation of the variables. The research targeted Internal Auditors, Banking/Fosa managers, Finance Managers and Risk managers of licensed deposit taking SACCO societies operating within Nakuru County selected using simple random sampling method to achieve a response level of at least 30\%.Data was collected using questionnaires which were tested for validity and reliability. The research findings revealed that not all SACCOs have implemented treasury risk management practices in their treasury operations thus some had not identified the specific risks facing their treasury operations. The collected data was analyzed and tested using t-test on SSPSS version 20. The analyzed dataconfirmed that the implementation of treasury risk management practices has an effect on the regulatory compliance of some selected financial ratios and the financial performance of SACCO Societies.
\end{abstract}

Keywords: Deposit-Taking SACCO, treasury risk management, financial performance.

\section{Introduction}

Treasury management has been and is still a global concern not only in formal corporate world but also in informal financial sector (Shiller, 2012). Unlike banks Sacco's have been adversely affected due lack of expertise management, financial muscles and in-depth awareness in the management of treasury (Mehran, Morrison, \& Shapiro, 2012). For centuries, no single definition can be termed as precise and complete, comprehensively outlining the concept of treasury management in depth. However, one such definition that has gained general acceptance is that Treasury management is the overall administration of a corporate's cash flow as well as the creation and governance of policies and procedures that ensure the company manages risk successfully (Lam, 2014; Polak, Robertson, \& Lind, 2011).

Raussand (2013) states that, historically treasury management was centered on Working Capital management this became more evident when during the 1992/93 World Financial crisis, most countries that were able to avoid its worst effects were those that used capital controls in managing their economies and financial sector (Epstein, Grabel , \& Jomo, 2003). In their study, Epstein, Grabel , \& Jomo (2003) seek to demonstrate that capital controls in many developing countries have made numerous important achievements in their economic development and stability. Thus the importance of capital controls at the national level.

Treasury risk management is the process of managing a firm's liquidity, mitigating its operational, financial and reputational risk(Lam, 2014).The objective of treasury risk management is to provide an independent measurement and monitoring the market and other risks being undertaken across various treasury businesses. It requires clear reporting with parameter (metrics) linked to the control of risks arising from trading and other treasury operations (Van Greuning \& Brajovic, 2003) In view of the above functions therefore, treasury risk management is an umbrella term which reffers to a collection of functions all geared towards the 
management and control of cash; that is, liquidity management. This not forgetting the risk management aspect to ensure that the cash in question either retains or increases its value.

With the launching of the SACCO Societies Regulatory Authority and the Enactment of the SACCO societies (Deposit Taking SACCO business) Regulations, 2010, more pressure has been put on SACCOs to ensure more professional operations management. The strict compliance requirements and increased competition from banks with a more informed membership has added pressure to the societies operations thus the inevitable need to change from the traditional cash management practices to a more professional treasury management with specific attention to risk control and management.

While a lot of attention has been concentrated on Banks treasury risk management, until recently, very little attention has been drawn to SACCO societies' practices of treasury risk management. Njagi, (2009) looked at effectiveness of know your customer policies adopted by commercial banks in Kenya in reducing money laundering and fraud incidences. Waweru, (2011) Carried out an investigation into the cash management challenges in Savings and Credit co-operatives (SACCOs) in Nakuru County, Kenya. Wanjiru, (2011) Studied strategic responses of Equity Bank to fraud related risks and Ogol, (2011) Studied Liquidity risk management practices in microfinance institutions in Kenya. These studies have mainly concentrated on Fraud and liquidity risk which is just but a portion of the risks facing treasury management. The question therefore remains as to whether deposit taking SACCO Societies have adopted professional treasury risk management practices in their day to day treasury operations, and whether this implementation has enabled them improve on their liquidity and general financial performance and thus ensuring compliance with the requirements of the SACCO Societies (Deposit-taking SACCO business) regulations 2010 in terms of liquidity maintenance requirements.

The study aims to establish the risk management practices adopted by SACCO societies in their day to day treasury management in the current advent of more informed membership and staff force and the effectiveness of these measures as reflected in the Societies' Liquidity and general financial performance. This study therefore aims to look into the risk management strategies and practices adopted by deposit taking SACCO Societies in Kenya in their day to day treasury management operations and how they affect the Societies' Liquidity performance. It also seeks to inquire on where deposit- taking SACCO Societies go wrong in their treasury management practices thus exposing their funds to risk resulting to possible non-compliance with the required liquidity ratios and low financial performance.

\section{Research Methodology}

Survey study research design was used for this study. This was chosen as it describes in depth the nature of the phenomenon and examines actions as they happen rather than manipulation of variables(De Vaus, 2013) This design was preferred because it takes data from a sample of a given population, in order to make assumptions about that population. The target population for this study wasInternal Auditors, Banking/ Fosa Managers, Finance Manager and Risk Managers of all the registered and licensed deposit taking SACCO societies operating within Nakuru County. There are 160 Licenced and registered Deposit taking SACCO societies in Kenya of which (five) 5 have restricted licensing of up to $30^{\text {th }}$ June 2015 . Of the Fully licensed SACCOs, Nakuru county accounts for 4 fully licensed deposit taking SACCO societies (i.e those whose registered offices are based within Nakuru county). Considering that the sample was very small the target group was set to be be atleast three officers of all the SACCOs operating within Nakuru County either as head office or by virtue of a branch representation. This accounted for 12 Fully Licensed SACCO Societies. This enabled the researcher achieve a good representative of the population to cover for the instances where some questionnaires were not responded to. The sampling procedure used in arriving at these specific SACCOs was Simple Random Sampling. This ensured that each element in the population had an equal opportunity of being selected. A questionnaire was used for data collection because it offers considerable advantages in its administration. Two types of validity were examined in this study namely; face validity and content validity. During the construction of the data collection instrument in this study, validity was be ensured through face validity, where the instrument was subjected to two experts to check whether it will measure what it is intended to measure and content validity, where the instrument was designed according to the study variables. Piloting of the study was carried out to enable the researcher assess the clarity of the questionnaire items and those items which were found to be inadequate or vague were modified to improve the quality of the research instrument, thus increasing its reliability. . Cronbanch alpha coefficient tests were run to test the reliability of the sollected data. Risk managemen practices had a cronbanch alpha value of (0.764), Compliance level (0.767) and Financial performance (0.785) these are above the minimum measure of 0.6 and thus were considered reliable. The research data was obtained from both primary and secondary sources. The data was then summarized, coded, tabulated and analysed using both descriptive and inferential statistics. Descriptive statistics included those of the mean, standard deviation and frequency distribution while inferential statistics involved the use of multiple regression analysis. Data presentation was done by the use of pie charts, bar charts, percentiles and frequency tables. This ensured that the gathered information would be clearly understood. SPSS Version 20 was used to 
perform the analysis as this aide in organizing and summarizing the data by the use of descriptive statistics such as tables. A linear regression analysis was also carried out on the data to confirm whether there exists any relationship between treasury risk management practices and the regulatory compliance of selected compliance ratios and between treasury risk managemetn practices and the financial performance of the SACCO societies as measured by the CAMEL rating system of bank supervision.

\section{Research Results}

The respondents to the questionnaires were analyzed according to their asset base, number of branches, Fosa/Banking hall operation structure, risk managament responsibility and treasury risk documentation.

3.1 Asset base distribution

on the basis of Asset base, All the Societies from whom responses were received had a asset base of between one billion shillings and five billion shillings (Sh. 1,000,000,000 - Sh. 5,000,000,000). The distribution was as presented bellow.

Table 3: Asset Base Distribution

\begin{tabular}{|l|l|l|}
\hline Asset Value & Frequency & Percentage \\
\hline Up to Sh. 1,000,000 & 0 & $0 \%$ \\
\hline From Sh. 1,000,001 to Sh. 100,000,000 & 0 & $0 \%$ \\
\hline From Sh. 100,000,001 to 500,000,000 & 0 & $0 \%$ \\
\hline From Sh. 500,000,001 to Sh. 1.000,000,000 & 0 & $0 \%$ \\
\hline From Sh. 1,000,000,001 to 5,000,000,000 & 6 & $100 \%$ \\
\hline From Sh. 5,000,000,001 and above & 0 & $0 \%$ \\
\hline Total & $\mathbf{6}$ & $\mathbf{1 0 0 \%}$ \\
\hline
\end{tabular}

Source: Survey Data, 2015

This implies that the societies in question were operating at an almost equal operational level and by virtue of their asset base, the Societies can be said to have similar operational capacity. According to the SASRA's SACCO peergroup ranking, the above societies are ranked as Medium Sized SACCOs(SASRA;, 2014).

\subsubsection{Number of branches}

Basing on the number of branches, $50 \%$ of the respondents have five and more fully operational branches within the country. The distribution of the respondent in accordance to the branch network is as follows.

Table 4: Number of Branches

\begin{tabular}{|l|l|l|}
\hline Number of branches & Frequency & Percentage \\
\hline One Branch & 0 & $0 \%$ \\
\hline Two Branches & 1 & $16.66 \%$ \\
\hline Three Branches & 1 & $16.67 \%$ \\
\hline Four Branches & 1 & $16.67 \%$ \\
\hline Five and above & 3 & $50 \%$ \\
\hline Total & $\mathbf{6}$ & $\mathbf{1 0 0 \%}$ \\
\hline
\end{tabular}

Source: Survey Data, 2015

The number of branch networks shows the operational size and accesibility of the services offered by the Societies to its membership (SASRA; 2014).

\subsubsection{FOSA/ Banking Hall Operation Structure}

Table 5: FOSA/Banking Hall Operation Structure

\begin{tabular}{|l|l|l|}
\hline FOSA Operation Structure & Frequency & Percentage \\
\hline Banking Manager, Chief Teller, Custodian, Tellers & 3 & $33.33 \%$ \\
\hline Finance Officer, Chief Teller, Custodian, Tellers & 0 & $0 \%$ \\
\hline Fosa Manager, Custodian, Tellers & 3 & $66.67 \%$ \\
\hline Other & 0 & $0 \%$ \\
\hline Total & $\mathbf{6}$ & $\mathbf{1 0 0 \%}$ \\
\hline
\end{tabular}

\section{Source: Survey Data, 2015}

The banking hall operational structure is an indication of the basic structural controls put in place to manage treasury risks as and when they occur. This is in line with the three lines of defence risk management strategy.

\subsubsection{Risk Management Responsibility}

The International Standards for the Proffesional Practice of Internal Auditng (IPPF), provides under Section 2120C3 that, when assisting management in establishing or improving the risk management process, Internal Auditors must refrain from assuming any management responsibility by actually managing risks. From 
the response analysis, on one Society representing $16.67 \%$ of the respondents had separated the risk management function from the Internal Audit department as illustrated bellow.

Table 6: Risk Management Responsibility

\begin{tabular}{|l|l|l|}
\hline Treasury Risk Management and control responsibility & Frequency & Percentage \\
\hline Internal Audit & 5 & $83.33 \%$ \\
\hline Risk Management Department & 1 & $16.67 \%$ \\
\hline Total & $\mathbf{6}$ & $\mathbf{1 0 0 \%}$ \\
\hline
\end{tabular}

Source: Survey Data, 2015

While studying liquidity risk management practices in microfinance institutions, (Ogol, 2011) found out that, the organizational sructure and operating environments of microfinance institutions provide unique structures. Ogol, (2011) reccomended that, the organization structure and incentive system should be aligned with the goals and objectives of the risk management program.

\subsubsection{Treasury risk documentation}

The response revealed that, only one of the SACCO Soceities interviewed did not maintain a risk register and as such has not identified its treasury risk exposure level. The response analysis were as documented in the table bellow

Table 7: Treasury Risk Documentation

\begin{tabular}{|l|l|l|}
\hline Treasury risk register & Frequency & Percentage \\
\hline Maintained & 5 & $83.33 \%$ \\
\hline Not maintained & 1 & $16.67 \%$ \\
\hline Total & $\mathbf{6}$ & $\mathbf{1 0 0 \%}$ \\
\hline
\end{tabular}

Source: Survey Data, 2015

In his book on Enterprise risk management; From incentive to controls, Lam, 2014 points out that risk control lies on the internal control measures that are set to ensure that risks are identified as soon as they occur and the whole management process is effectively documentated and communicated for viability. The main tool for risk documentation and analysis is the risk register. In a related study, Ambira \& Kemoni, (2011) found out that Commercial banks used internal ratings and classified borrowers in different risk levels in Kenya. However, the study further revealed that the banks had inadequate records management practices which in turn undermined the risk management function.

\subsection{Inferential analysis}

This section summarizes the research data and findings presented and analyzed on the basis of the research questions. The data summary will mainly be presented in form of tables and figures will be used to present where appropriate.

\subsubsection{Types of treasury risks faced by SACCO Societies operating in Nakuru County}

The respondents were asked to list any five kinds of risks faced by their societies in their course of treasury operations and indicate the risk exposure as per their risk registers as at $31^{\text {st }}$ December 2014 . The response was from five Societies that maintained a risk register as follows.

Table 8: Identified Treasury Risks and exposure levels

\begin{tabular}{|c|c|c|c|c|c|c|}
\hline 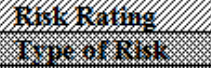 & WIII & 7.6." & 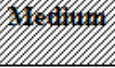 & 740 & 619 & 707 \\
\hline r. & 0 & 0 & 0 & 0 & 5 & 5 \\
\hline$x_{1} x_{1}$ & 0 & 1 & 3 & 1 & 0 & 5 \\
\hline 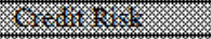 & 0 & 0 & 3 & 1 & 1 & 5 \\
\hline 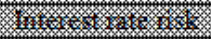 & 0 & 2 & 1 & 2 & 0 & 5 \\
\hline$x_{1} x_{1} x_{1}$ & 0 & 3 & 2 & 0 & 0 & 5 \\
\hline H. & 0 & 1 & 1 & 0 & 0 & 2 \\
\hline , & 3 & 1 & 0 & 1 & 0 & 5 \\
\hline
\end{tabular}

Source: Survey Data, 2015

The response indicate that Fraud risk is the highest risk facing SACCO societies where all the respondents have their exposure rating to this risk as high. Liquidity risk and Interest rate risk follow with medium exposure bearing the highest frequency then operational risk. Most societies had low risk exposure to reputation risk with investment risk being identified by only two societies with a risk exposure of medium to medium low. 
In the annual supervision report, the regulator, SASRA identified that among the top complains and inquiries done on deposit taking SACCO societies in 2014, is suspected fraudulent management, embezzlement of members funds and other incidences of related fraud complaints (SASRA, 2014).

\subsubsection{Risk control measures put in place to mitigate against treasury risks}

In the book "Cybernetic approach to project Management", Lent, (2013) identified four risk management strategies. the respondents were asked to identify the strategies employed for the five commonly identified risks and the response was as follows.

Table 9: Treasury Risk Control Measures

\begin{tabular}{|c|c|c|c|c|c|}
\hline 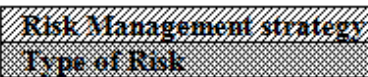 & Tis & 79. & 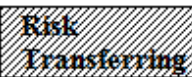 & 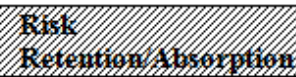 & 767 \\
\hline 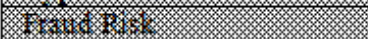 & 0 & 0 & 5 & 0 & 5 \\
\hline$\frac{m}{m}$ & 0 & 4 & 1 & 0 & 5 \\
\hline 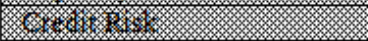 & 0 & 4 & 1 & 0 & 5 \\
\hline Mm & 0 & 4 & 0 & 1 & 5 \\
\hline 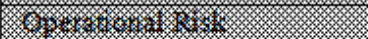 & 0 & 2 & 3 & 0 & 5 \\
\hline M & 5 & & 0 & 0 & 5 \\
\hline 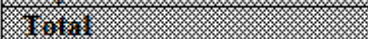 & 5 & 14 & 10 & 1 & 30 \\
\hline
\end{tabular}

Source: Survey Data, 2015

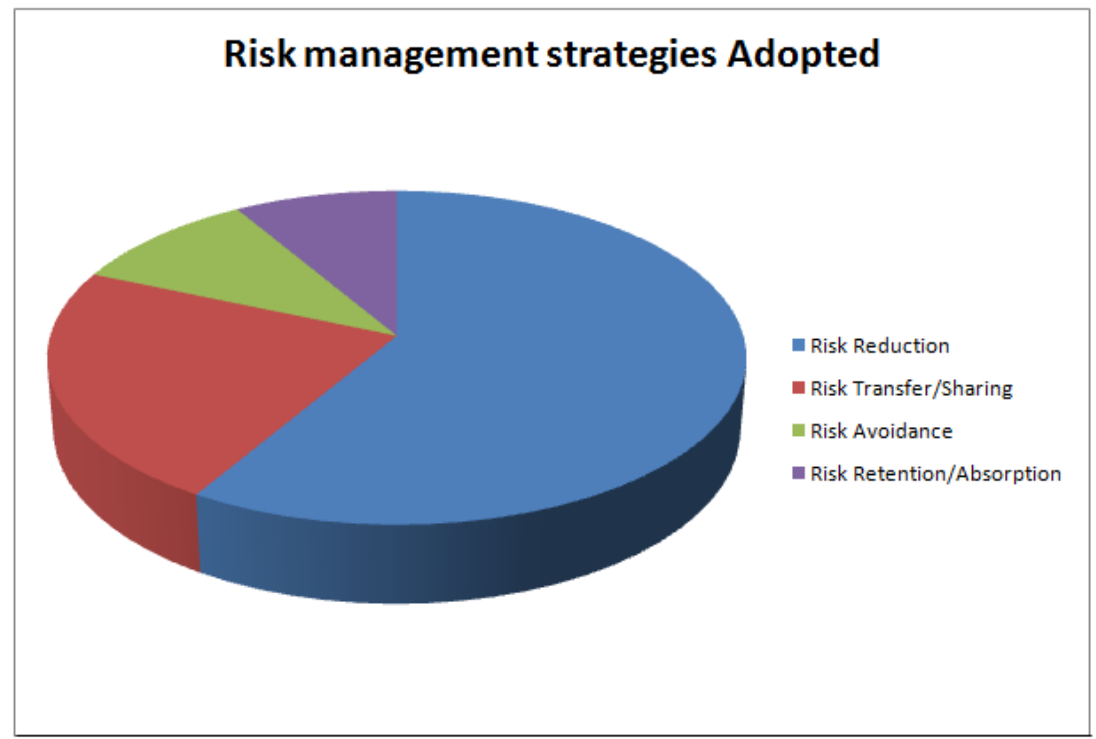

Figure 1.4: Risk Management strategies adopted

\section{Source: Survey Data, 2015}

From the chart above, the most common risk management strategy adopted by SACCO Societies operating within Nakuru County is risk reduction where the societies have minimized/mitigated against the risk exposure and closely monitor the risks so as to keep them within the acceptable limits. Followed by Risk transferring or sharing where the risk has been transferred or is shared with a third party then risk avoidance where the society has completely eliminated the risk and is no longer involved in its management. The least adopted strategy is risk absorption where the society accepts the value for the risk and even provides for it in its annual budget. While studying the effect of credit risk management practices in lending portfolio among Savings and Credit Cooperatives in Kenya, Langat, Mugo, \& Otuya, ( 2013) found out that, for SACCOs in Kenya, the use of tight risk mitigation policies such as insurance cover and diversification strategies influenced their lending portfolio.

\subsubsection{The Societies Level of Financial Performance Associated with the management of the treasury risks} identified

The level of financial performance was measured on the basis of regulatory compliance and on CAMEL rating system of bank supervision. For reasons of confidentiality, the respondents' identity shall be concealed in this analysis and the Societies shall be identified by the codes S1, S2, S3, S4, S5 and S6. 


\subsubsection{Regulatory Compliance}

Table 10: Regulatory Ratios

\begin{tabular}{|c|c|c|c|c|c|c|c|}
\hline Society & \multirow{2}{*}{$\begin{array}{l}\text { Minimum } \\
\text { regulatory } \\
\text { requirement }\end{array}$} & \multirow[t]{2}{*}{ S1 } & \multirow[t]{2}{*}{ S2 } & \multirow[t]{2}{*}{ S3 } & \multirow[t]{2}{*}{ S4 } & \multirow[t]{2}{*}{ S5 } & \multirow[t]{2}{*}{ S6 } \\
\hline 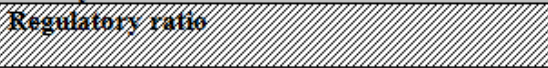 & & & & & & & \\
\hline Liquidity Ratio & Minimum 15\% & $8.82 \%$ & $15 \%$ & $12 \%$ & $18.70 \%$ & $9.95 \%$ & $15 \%$ \\
\hline Land and Building to total Assets Ratio & Maximum $5 \%$ & $0.26 \%$ & $2 \%$ & $0.54 \%$ & $0.09 \%$ & $7.42 \%$ & $4.5 \%$ \\
\hline Financial Investments to Deposit Liability Ratio & Maximum $5 \%$ & $2.47 \%$ & $1.5 \%$ & $2.39 \%$ & $0.08 \%$ & $2.69 \%$ & $2.3 \%$ \\
\hline Non- Earning Assets to total assets ratio & Maximum $10 \%$ & $7.38 \%$ & $9.2 \%$ & $1.35 \%$ & $0.86 \%$ & $9.04 \%$ & $7 \%$ \\
\hline
\end{tabular}

Source: Survey Data, 2015

To enable data comparison for purposes of decision making, the above data was graded on the score of " 1 " for compliance and " 0 " for non-compliance. The results were as follows;

Table 11: Compliance Score

\begin{tabular}{|l|l|l|l|l|l|l|}
\hline Society & S1 & S2 & S3 & S4 & S5 & S6 \\
\hline Liquidity Ratio & 0 & 1 & 0 & 1 & 0 & 1 \\
\hline Land and Building to total Assets Ratio & 1 & 1 & 1 & 1 & 0 & 1 \\
\hline Financial Investments to Deposit Liability Ratio & 1 & 1 & 1 & 1 & 1 & 1 \\
\hline Non- Eaming Assets to total assets ratio & 1 & 1 & 1 & 1 & 1 & 1 \\
\hline TOTAL SCORE & 3 & 4 & 3 & 4 & 2 & 4 \\
\hline
\end{tabular}

Source: Survey Data, 2015

The above data was then compared with the Societies, risk management structure, risk management responsibility and risk documentation to establish whether the compliance performance had any bearing in the risk management practices adopted by the societies. Risk documentation was rated on the basis that the society maintained a risk register and was guided by a risk management policy. The risk management structure was based on the involvement of all treasury staff in risk management and the risk management responsibility based on the existence of a risk management department or use of any other department other than the Internal Audit department. This are scored as 1 for a YES and 0 for a NO. The data analysis results basing on the above parameters was as follows.

Table 12: Risk Management Practice Score

\begin{tabular}{|c|c|c|c|c|c|c|}
\hline Society & \multirow[t]{2}{*}{ S1 } & \multirow[t]{2}{*}{ S2 } & \multirow[t]{2}{*}{ S3 } & \multirow[t]{2}{*}{ S4 } & \multirow[t]{2}{*}{ S5 } & \multirow[t]{2}{*}{ S6 } \\
\hline 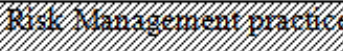 & & & & & & \\
\hline Risk Responsibility & 0 & 0 & 0 & 0 & 0 & 1 \\
\hline Risk structure & 1 & 1 & 0 & 0 & 0 & 1 \\
\hline Risk Documentation & 1 & 1 & 1 & 0 & 1 & 1 \\
\hline TOTAL SCORE & 2 & 2 & 1 & 0 & 1 & 3 \\
\hline $8011<1<1<1<1<$ & 8 & $x$ & 奖 & 4 & $x$ & 6 \\
\hline
\end{tabular}

Source: Survey Data, 2015

From the above analysis, Society, S4, with a risk management practice score of 0 has met the highest compliance score of 4 . It can therefore be concluded that risk management practices do not have an influence on the compliance of the regulatory requirements for the selected ratios affecting a society's liquidity. In his study on commercial banks versus rural SACCOs in Tanzania, Magali \& Qiong, (2014) found that banks have effective credit risk management practices than the rural SACCOs thus while banks were making $100 \%$ profits, SACCOs were only making $30 \%$ profits. They concluded that like banks, there was need for SACCO societies to embrace risk management practicesin order to improve on their financial performance.

\subsubsection{CAMEL rating system of Bank Supervision}

When other Financial Performance measures, i.e. Capital Adequacy, Asset Quality, Management Quality, Earnings Ability and Liquidity management (CAMEL) were incorporated into the analysis, the results were as follows;

Table 13: CAMEL Score

\begin{tabular}{|l|l|l|l|l|l|l|}
\hline Society & S1 & S2 & S3 & S4 & S5 & S6 \\
\hline Risk management practice score & 2 & 2 & 1 & 0 & 1 & 3 \\
\hline CAMEL score & $\mathbf{l}$ & $\mathbf{2}$ & $\mathbf{3}$ & $\mathbf{3}$ & $\mathbf{3}$ & $\mathbf{1}$ \\
\hline
\end{tabular}

Source: Survey Data, 2015 
Where;

A Score of 1 indicates Sound Financial Performance; a Score of 2 indicates Fundamentally Sound performance, a score of 3 indicates generally weak performance, a score of 4 indicates weak performance and a score of 5 indicates poor performance.

From the above findings, Societies S1 and S6 scored 1 indicating Sound Financial performance. According to the CAMEL rating system of banking supervision, this score indicates Substantial compliance with laws and regulations, stable financial performance with strong risk management practices. Society S2 had a CAMEL score of 2 indicating fundamentally sound financial performance which signifies that the society has substantially complied with laws and regulations and has moderate weaknesses with satisfactory risk management practices. Societies S3, S4 and S5 had a CAMEL score of 3 each indicating weak performance thus signifying that the Societies had general weaknesses in one or more component areas and are vulnerable to external influences with less than satisfactory risk management practices. The SACCO Societies regulatory authority affirms the use of the CAMEL rating system which it has also adopted in carrying out risk based supervision of Deposit taking SACCO Societies in Kenya (SASRA;, 2014).

\subsubsection{Statistical analysis}

Linear regression analysis and t-test statistics were carried out on to test whether the practice of treasury risk management has an effect on the compliance of SACCO societies with the selected regulatory ratio requirements and whether the implementation of treasury risk management practices has an effect on the Financial performance of the SACCO Societies, financial performance inthis case being measured on the basis of CAMEL system of bank supervision. The data was run through SPSS version 21 and the results were as follows;

Testing the null hypothesis there is a significant relationship between the practice of treasury risk management and regulatory compliance at $95 \%$ confidence level

Table14. Pearson Correlation coefficient for Compliance score Correlations

\begin{tabular}{|ll|l|l|}
\hline & & $\begin{array}{l}\text { Compliance } \\
\text { score }\end{array}$ & $\begin{array}{l}\text { Risk } \\
\text { management }\end{array}$ \\
\hline Pearson Correlation & Compliance score & 1.000 & -.127 \\
& Risk management & -.127 & 1.000 \\
Sig. (1-tailed) & Compliance score & & -406 \\
& Risk management & 406 & - \\
$\mathrm{N}$ & Compliance score & 6 & 6 \\
& Risk management & 6 & 6 \\
\hline
\end{tabular}

Source; Survey data 2015

Table15. t-test for compliance score

\begin{tabular}{|c|c|c|c|c|c|c|c|c|c|c|c|c|}
\hline \multirow[b]{2}{*}{ Model } & \multicolumn{2}{|c|}{$\begin{array}{l}\text { Unstandardi } \\
\text { zed } \\
\text { Coefficients }\end{array}$} & \multirow{2}{*}{$\begin{array}{l}\text { Standardi } \\
\text { zed } \\
\text { Coefficie } \\
\text { nts } \\
\\
\text { Beta } \\
\end{array}$} & \multirow[b]{2}{*}{$\mathrm{t}$} & \multirow[b]{2}{*}{ Sig } & \multicolumn{2}{|c|}{$\begin{array}{l}95.0 \% \\
\text { Confidence } \\
\text { Interval for B }\end{array}$} & \multicolumn{3}{|c|}{ Correlations } & \multicolumn{2}{|c|}{$\begin{array}{l}\text { Collinearity } \\
\text { Statistics }\end{array}$} \\
\hline & $\mathrm{B}$ & $\begin{array}{l}\text { Std. } \\
\text { Error }\end{array}$ & & & & $\begin{array}{l}\text { Lowe } \\
\mathrm{r} \\
\text { Boun } \\
\mathrm{d} \\
\end{array}$ & $\begin{array}{l}\text { Upp } \\
\text { er } \\
\text { Bou } \\
\text { nd }\end{array}$ & $\begin{array}{l}\text { Zero- } \\
\text { order }\end{array}$ & $\begin{array}{l}\text { Parti } \\
\text { al }\end{array}$ & $\begin{array}{l}\mathrm{Pa} \\
\mathrm{rt}\end{array}$ & $\begin{array}{l}\text { Toler } \\
\text { ance }\end{array}$ & VIF \\
\hline $\begin{array}{c}1 \text { (Con } \\
\text { stant } \\
)^{2}\end{array}$ & $\begin{array}{l}3.3 \\
03\end{array}$ & .633 & & $\begin{array}{l}5.2 \\
14\end{array}$ & $\begin{array}{l}.00 \\
6\end{array}$ & 1.544 & $\begin{array}{l}5.06 \\
2\end{array}$ & & & & & \\
\hline $\begin{array}{c}\text { Risk } \\
\text { ma } \\
\text { nage } \\
\text { ment }\end{array}$ & $\begin{array}{l}- \\
.09 \\
1\end{array}$ & .356 & -.127 & $\begin{array}{l}- \\
.25 \\
5\end{array}$ & $\begin{array}{l}.81 \\
1\end{array}$ & $\begin{array}{l}- \\
1.079\end{array}$ & .897 & -.127 & $\begin{array}{l}- \\
.127\end{array}$ & $\begin{array}{l}- \\
.1 \\
27\end{array}$ & 1.000 & $\begin{array}{l}1.00 \\
0\end{array}$ \\
\hline
\end{tabular}

Source; Survey Data 2015

Table16. Correlation Coefficient (Compliance score) Coefficient Correlations $^{\text {a }}$

\begin{tabular}{|lll|l|}
\hline Model & & & $\begin{array}{l}\text { Risk } \\
\text { management }\end{array}$ \\
\hline 1 & Correlations & Risk management & 1.000 \\
& Covariance's & Risk management & .127 \\
\hline
\end{tabular}

a. Dependent Variable: Compliance score

Source; Survey data 2015 
A one tailed significant value of 0.811 was achieved which is greater than 0.05 thus indicating that there is no statistically significant difference between treasury risk management practices and regulatory compliance. A Pearson's correlation coefficient of 1 confirmed that there is a strong correlation between the practice of treasury risk management and regulatory compliance of the selected ratios.

Testing the null hypothesis there is a significant relationship between the practice of treasury risk management and financial performance at $95 \%$ confidence level;

Table17. t-test for financial performance

Coefficients $^{\mathrm{a}}$

\begin{tabular}{|c|c|c|c|c|c|c|c|c|c|c|c|c|}
\hline \multirow[b]{2}{*}{ Model } & \multicolumn{2}{|c|}{$\begin{array}{l}\text { Unstandardize } \\
\text { d Coefficients }\end{array}$} & \multirow{2}{*}{$\begin{array}{l}\text { Standa } \\
\text { rdized } \\
\text { Coeffi } \\
\text { cients }\end{array}$} & \multirow[b]{2}{*}{$\mathrm{t}$} & \multirow[b]{2}{*}{ Sig. } & \multicolumn{2}{|c|}{$\begin{array}{l}95.0 \% \\
\text { Confidence } \\
\text { Interval for } \\
\text { B }\end{array}$} & \multicolumn{3}{|c|}{ Correlations } & \multicolumn{2}{|c|}{$\begin{array}{l}\text { Collinearity } \\
\text { Statistics }\end{array}$} \\
\hline & B & $\begin{array}{l}\text { Std. } \\
\text { Error }\end{array}$ & & & & $\begin{array}{l}\text { Low } \\
\text { er } \\
\text { Boun } \\
\text { d } \\
\end{array}$ & $\begin{array}{l}\text { Up } \\
\text { per } \\
\text { Bo } \\
\text { und }\end{array}$ & $\begin{array}{l}\text { Zer } \\
\text { o- } \\
\text { ord } \\
\text { er }\end{array}$ & $\begin{array}{l}\text { Part } \\
\text { ial }\end{array}$ & Part & $\begin{array}{l}\text { Toler } \\
\text { ance }\end{array}$ & VIF \\
\hline $\begin{array}{ll}1 & \text { (Consta } \\
& \text { nt) } \\
& \text { Risk } \\
& \text { manage } \\
& \text { ment }\end{array}$ & $\begin{array}{l}3.394 \\
-.818\end{array}$ & $\begin{array}{l}.407 \\
.229\end{array}$ & -.873 & $\begin{array}{l}8.33 \\
6 \\
- \\
3.57 \\
6\end{array}$ & $\begin{array}{l}.001 \\
.023\end{array}$ & $\begin{array}{l}2.26 \\
4 \\
- \\
1.45 \\
3\end{array}$ & $\begin{array}{l}4.5 \\
24 \\
- \\
.18 \\
3\end{array}$ & $\begin{array}{l}- \\
.87 \\
3\end{array}$ & $\begin{array}{l}- \\
.87 \\
3\end{array}$ & $\begin{array}{l}- \\
.87 \\
3\end{array}$ & $\begin{array}{l}1.00 \\
0\end{array}$ & $\begin{array}{l}1.00 \\
0\end{array}$ \\
\hline
\end{tabular}

a. Dependent Variable: Financial performanceSource; Survey data 2015

Table18. Durbin-Watson statistic measure

Model Summary ${ }^{b}$

\begin{tabular}{|c|c|c|c|c|c|c|c|c|c|c|}
\hline \multirow{2}{*}{$\begin{array}{l}\text { Mod } \\
\text { el }\end{array}$} & \multirow[t]{2}{*}{$\mathrm{R}$} & \multirow{2}{*}{$\begin{array}{l}\mathrm{R} \\
\text { Square }\end{array}$} & \multirow{2}{*}{$\begin{array}{l}\text { Adjusted } \\
\text { R Square }\end{array}$} & \multirow{2}{*}{$\begin{array}{l}\text { Std. Error } \\
\text { of the } \\
\text { Estimate }\end{array}$} & \multicolumn{5}{|c|}{ Change Statistics } & \multirow{2}{*}{$\begin{array}{l}\text { Durbin- } \\
\text { Watson }\end{array}$} \\
\hline & & & & & $\begin{array}{l}\mathrm{R} \text { Square } \\
\text { Change }\end{array}$ & \begin{tabular}{|l} 
F \\
Change
\end{tabular} & df1 & df2 & \begin{tabular}{|ll} 
Sig. & F \\
Change & \\
\end{tabular} & \\
\hline 1 & $.873^{\mathrm{a}}$ & .762 & .702 & .537 & .762 & 12.789 & 1 & 4 & .023 & 2.175 \\
\hline
\end{tabular}

a. Predictors: (Constant), Risk management

b. Dependent Variable: Financial management

Source; Survey data 2015

A one tailed significant value of 0.023 was achieved which less than 0.05 is thus indicating that there is a statistically significant difference between treasury risk management practices and financial performance. A Correlation coefficient of 0.702 confirmed that there is a correlation between the practice of treasury risk management and regulatory compliance of the selected ratios.

All the societies reviewed were of an almost same size as indicted by the asset value but at different stages of growth as indicated by the branch networks. The main objective of the study was to establish the measures put in place by SACCO Societies to deal with the major risks associated with treasury management in the current advent of a more informed membership and staff force and the effectiveness of these measures as reflected in the Societies liquidity and general financial performance.

\section{Discussion}

Most of the societies reviewed had adopted a risk reduction strategy where the societies minimize or mitigate the risks to acceptable levels then keeps monitoring them to keep their probability of occurrence low. Whereas all the societies reviewed apart from Society S4 had adopted risk management practices to some level, the societies except Society S1, S2 and S6 have not cascaded the risk management function to the actual risk owners, in this case the head of the treasury section. The societies have left the responsibility of risk management to the Internal Auditors who are limited by their professional standards on the extent of their involvement in the whole risk management function. A statistical analysis of the findings revealed that the implementation of treasury risk management practices has an effect on both the regulatory compliance and financial performance of SACCO Societies. 


\section{Conclusion}

On the basis of the research findings, it can thus be concluded that, not all SACCO Societies operating within Nakuru County have adopted risk management practices that could enable them identify the risks facing their day to day treasury risk operations as evidenced by the risk management score. However, the societies that analysed their risk exposure identified, Fraud risk as the highest risk facing their treasury operations thus more measures need to be put in place to manage this risk.

The most common treasury risk management and control measure put in place by SACCO Societies is risk reduction which involves the minimization of risks to acceptable limits then closely monitoring it to keep its probability of occurrence low. However, the societies have not adopted an all-inclusive risk management structure which involves all the staff at all levels of treasury operations thus enabling risk detection at its earliest stage of occurrence. Finally, the practice of treasury risk management has a significant effect on the regulatory compliance and financial performance of deposit taking SACCO Societies operating within Nakuru County. In this case therefore, SACCOs have to implement good and efficient treasury risk management practices for them to fully comply with the regulatory compliance ration requirements and for improved financial performance.

\section{Recommendations}

Considering that treasury operations, being the management of funds which is the lifeblood of the Societies, SACCO Societies should implement sound treasury risk management practices so as to ensure that they maintain a competitive edge as an investment option amongst other players in the financial industry as backed up by their financial stability.

\section{Suggestions for further research}

This research only concentrated on the effect of treasury risk management on the financial performance of SACCO Societies. However, financial performance is also affected by other aspects such as the capital management, governance practices and the personnel management skills among other factors. The effectiveness of treasury risk management is also dependent on the personnel skills and availability of resources which did not form part of this research. These therefore form the basis for further research in this field.

\section{References and Bibliography}

[1]. Ahrens, J., \& Rudolph, P. M. (2006). The importance of governance in risk reduction and disaster managment. Journal of Contigencies and Crisis Managment, 14(4), 207-220.

[2]. Altman, E. I., \& Hotchkiss, E. (2010). Coporate Financial Distress and Bankruptcy; Predict and avoid bankruptcy, analyze and invest in distressed debt (Vol. 289). John Wiley and Sons.

[3]. Altman, E., \& Hotchkiss, E. (2006). Corporates Financial Distress and Bankruptcy: Predict and Avoid Bankruptcy, Analyze and Invest in Distressed Debt (3RD ed.). USA: John Wiley \& Sons.

[4]. Ambira, C. M., \& Kemoni, H. (2011). Records Management and Risk Management at Kenya Commercial Bank Limited, Nairobi. SA Journal of Information Management, 13(1), 11-25.

[5]. Ballou, J. (2011, November 8). Open ended questions. Encyclopedia of Survey Research methods, pp. 548-550.

[6]. Banks, E. (2005). Liquidity Risk; Managing Asset and Funding Risk. NewYork: Palgrave Macmillan.

[7]. Bansal, M., Suman, \& Sonepat, M. (2014). Survey Paper on Credit Card Fraud Detection. International Journal of Advanced Research in Computer Engineering and Technology, 3(3), 827-832.

[8]. Bartlett, E. J., Kotrlik, W. J., \& Higgins, C. C. (2001). Organizational Research: Determining Appropriate Sample Size in Survey. Information Technology, Learning and Performance Journal, 19(1), 43-50.

[9]. Belland, B. R., French, B. F., \& Eitmer, P. A. (2009). Validity and problem based learning research; A review of instrunments used to asses intended learning outcomes. Interdiciplinary journal of problem based learning, 3(1), 5 .

[10]. Benn, S., \& Bolton, D. (2011). Key Concepts in Coporate Social Responsibilities. London: Britain.

[11]. Bessis, J. (2011). Risk Management in Banking. John Wiley and Sons.

[12]. Biegelman, M. T., \& Barton , J. T. (2012). Executive Roadmap to Fraud Prevention and Internal Controls: Creating a Culture of Compliance. USA: John Wiley \& Sons.

[13]. Birley, G., \& Moreland, N. (2014). A practical guide to Academic research. Routledge.

[14]. Borg, W. R., \& Gall, M. D. (1989). Educational Research (4th ed.). New York: Longman.

[15]. Boys, J. (2012). Forensic Accounting in New Zealand Exploring the GapBetween Education and Practice (5th ed.). Auckland, New Zealand: Auckland University of Technology.

[16]. Bragg, M. S. (2010). Treasury management; Practitioners guide. John Wiley \& Sons

[17]. Bryman, A., \& Bell, E. (2015). Business Research Methods (4th ed.). New York, USA: Oxford University Press

[18]. Buckhouff, T. A. (2004). The Forensic Target of Fraudsters. The Journal of Certified Public Accountants, 2(7), 7-19.

[19]. CFA Institute. (2007). Managing Investment Portfolios; a dynamic process (Vol. 3). (J. L. Maginn, D. L. Tuttle, D. W. McLeavey, \& E. J. Pinto, Eds.) John Wiley \& Sons.

[20]. Chang, Chian-Lin, Jimenez-Martin, Juan, A., McAleer, Michael, P., et al. (2011, February 21). Risk Management of Risk Under the Basel Accord; Forecasting Value at Risk of VIX Futures. Retrieved July 15, 2015, from http://ssrn.com/abstract=1765202.

[21]. Chapman, R. (2011). Simple tools and techniques for enterprise risk management. John Wiley and Sons.

[22]. Chernobai, A. S., Rachev, S. T., \& Fabozzy, F. J. (2008). Operational risk; A guide to Basel II Capital Requirements, Models and Analysis (Vol. 170). John Wiley \& Sons.

[23]. Chhaba, R., Dhalia, P., Mathur, P., \& Das, I. (2013, September 22nd). Social Science Research Network. Retrieved July 17th, 2015, from papers.ssrn.com: http://dx.doi.org/10.2139/ssrn.2329303

[24]. Choudhry, M. (2012). An Introduction to Credit Derivatives (2 ed.). Butterworth Heinemann.

[25]. Choudhry, M. (2012). The Principles of Banking. Singapore: John Wiley \& Sons Singapore pte. Ltd. 
[26]. Choudy, M. (2011). Bank Asset Liability Management; Strategy trading analysis. John Wiley \& Sons.

[27]. Cohen, L., \& Manion, L. (2010). A Guide to Teaching Practice. USA: Routledge.

[28]. De Vaus, D. (2013). Surveys in Social Research (6 ed.). New York: Routledge.

[29]. Easterby-Smith, M., Thorpe , R., \& Jackson, P. R. (2012). Management Research. London: Sage Publications Ltd.

[30]. Epstein, G., Grabel , I., \& Jomo, K. (2003). Capital Management Techniques in Developing countries: An Assesment of experiences from the 1990s and Lessons for the Future. University Of Massachussets Amherst. Political Economy Research Institute (PERI).

[31]. Ericsson, J., \& Renault, O. (2006). Liquidity and Credit risk. The Journal of Finance, 61(5), 2219-2250.

[32]. Evans, J., \& Lindsay, W. (2012). Managing for Quality and Performance Excellence. Cengage Learning.

[33]. Fabbozzi, F. J. (2010). Financial risk management. John Wiley \& Sons.

[34]. FBI. (2014). Authorization and Budget Request to Congress. NewYork: Department of Justice.

[35]. Fiorillo, A. (2006). Effect of Wholesale Lending to SACCOs in Uganda. Kampala: fsdu.or.ug.

[36]. Franc, R., \& Brown, K. (2011). Investment analysis and Portfolio management. Congage Learning.

[37]. Gay, I. (1992). Educational Research: Compentenciesfor Analysis and Application (4th ed.). New York: Mcmillan.

[38]. Gichira, R. N., \& Thambo, V. S. (2003). Youth Cooperative Program: Report of Technical Mission to Kenya, Tanzania and Zambia. Nairobi Kenya: English Printers.

[39]. Graeme, A. G., Campbell, G., Turner , J., \& Vanteeva, N. (2014). The Economic History Review: Corporate Ownership and Control in Victorian Britain. UK: John Wiley \& Sons Ltd.

[40]. Graham, A., \& Coyle, B. (2000). Cashflow Forecastign and Liquidity. Global Proffesional Publishi.

[41]. Graham, J., \& Kaye, D. (2006). A Risk Management Approach to Business Continuity; Aligning Business Continuity with Coporate Governance. Connecticut: Rothstein Associates Inc.

[42]. Grant, N. W. (2009). Bankruptcy and Insolvency Accounting: Practice and Procedure (7th ed., Vol. 1). New Jersey: John Wiley \& Son.

[43]. Gray, D. E. (2013). Doing Research in the Real World. London: Sage Publications.

[44]. Haimes, Y. Y. (2009). On thecomplex Definition of Risk; A System-Based Approach. Risk Analysis(12), 1647-1654.

[45]. Hair, J. F., Celsi, M. W., Money, A. H., Samouel, P., \& Page, J. M. (2015). Essentials of Business Research Methods (2th ed.). New York: Routledge.

[46]. Heid, F. (2007, December 12). The Cyclical effects of the Basel II Capital requirements. Journal of Banking and Finance, 3885 3900 .

[47]. Hubbard, G., Rice, J., \& Galvia, P. (2014). Strategic Management. Australia: Pearson.

[48]. Israel, G. D. (1992). Determining Sample Size. Florida: University of Florida Cooperative Extension Service, Institute of Food \& Agriculture sciences; EDIS.

[49]. Jensen, B. (2012, June 30). Fraud, American History. Retrieved Agust 08, 2012, from Trnity University web site: http://www.edu/rjensen/FraudAmericanhistory.htm

[50]. Jensen, H. (2010). The logic of qualitative survey research and it's position in the field of social research methods. In forum Qualitative. Sozialforschung/Forum, 11(2), 1-21.

[51]. Jeppesen, K. E., \& Rygel, W. (2014). Integrated Risk and Crisis Management. New York: Sentryx.com.

[52]. Jill, C., \& Hussey, R. (2013). Business Research; A practical guide for Undergraduate and postgraduate students. Palgrave Macmillan.

[53]. Kaplan, R. S., \& Norton, D. P. (2004). Strategy maps: Converting intangible assets into tangible outcomes. Havard Business Press

[54]. Kimberlin, C. L., \& Winstertein, A. G. (2008). Research Methods: Quantitative and Qualitative Approaches. A M J Health Syst Pharm, 65(23), 2276-84.

[55]. Klinke, A., \& Renn, O. (2001). Precautionary principle and discursive strategies; Classifying strategies: Classifying and managing risks. Journal of Risk Research, 4(2), 159-173.

[56]. Knight, F. H. (2012). Risk, Uncertainity and Ptofit. New York: Dover Publications.

[57]. Koller, T., Goedhart, M., \& Wessels, D. (2010). Valuation: Measuryng and Managing the value of companies (Vol. 499). John Wiley \& Sons.

[58]. Konthari, C. R. (2007). Research Methodology: Methods and Techniques (2nd ed.). New Delhi: New Age International Publishers.

[59]. Kotze, D. J., Zeeman, L., \& Roux, J. P. (2014). Back @ Work: Managing Change Following Unprotected Industrial Actions in Mining Industry. Management, 325-355.

[60]. Kumar , K. (2005). Methodology; A step by Step Guide for begginers. Addison, Australia: Wesley pty Ltd.

[61]. Lam, J. (2014). Enterprise risk Management: From Incentive to Controls. USA: John Wiley \& Sons.

[62]. Lando, D. (2009). Credit Risk Modelling; Theory and Applications. Priceton University Press.

[63]. Langat, F. K., Mugo, R. K., \& Otuya, R. I. (2013). Effect of Credit Risk Managment Practices in Lending Portfolio Among Savings and Credit Cooperatives in Kenya. International Journal of Science, Commerce and Humanities, 1(5), 33-56.

[64]. Lent, B. (2013). 13:00 Risk Management; RM in Cybernetic Approach to project management. Berlin Heidelberg: Springer.

[65]. Loughran, M. (2011). Fiancial Accounting for Dummies. England: John Wiley \& Sons.

[66]. Magali, J. J. (2014). The Influence of Leadership, Coporate governance and Regulations on Credit Risk Management;The study of Rural SACCOs from Tanzania. Management and Administrative Sciences, 3(2), 262-281.

[67]. Magali, J. J., \& Qiong, Y. (2014). Commercial Banks Versus Rural SACCOs credits Risk management practices in Tanzania. Journal of Economics and Sustainable development, 5(2), 33-45.

[68]. Makori, J., Munene, C., \& Muturi, W. (2013). The Challenges facing Deposit taking Savings and Credit Co-operatives in Kenya; A case of Gusii Region. Interdisciplinary Journal of Contemporary Research, 4(12), 103-1081.

[69]. Mathuva, M. D. (2010). The influence of Working Capital Management Components on Corporate Profitability: A Survey of Kenyan Listed Firms. Research Journal of Business Management, 1(4), 1-11.

[70]. Matumo, G. N., Maina, E. K., \& Ngugi, N. N. (2013, May). The Impact of Front Office SACCO ACtivity on SACCO Performance in Kenya; A case study of Meru South and Maara Districts in Tharaka Nithi County in Kenya. Global Advanced Research Journal of Management and Business Studies, 2(5), 285-290.

[71]. McNeil, A. J., Frey, R., \& Embrechts, P. (2005). Quantitative Risk Management; Concepts, Techniques and Tools. Princeton University Press.

[72]. Mehran, H., Morrison, A. D., \& Shapiro, J. D. (2012). Corporate Governance and Banks: What have we learned from the Financial Crisis? New York: FRB of New York Staff Report.

[73]. Morgan, D. P. (2000). "Rating banks: Risks uncertainity in an opaque industry". New York: FRB of NewYork Staff Report. 
[74]. Moser, M., Bohme, R., \& Breuker, D. (2013). An Injury into Money Laundering Tools in the Bitcoin Ecosystem. eCrime Researcher Summit (pp. 1-14). USA: IEEE.

[75]. Mudibo, E. K. (2005). Coporate Governance on Coperatives; The East African Experience. Pan African Consultative Forum on Coporate Governance. Dakar: Senegal.

[76]. Njagi, L. (2009). Effectiveness of Know Your Customer Policies adopted by Co-operative Banks in Kenya in Reducing Money Laundering Compliance Programs. Unpublished MBA Research, University Of Nairobi.

[77]. Njeru , D. M., Member, F., Tirimba, I. O., \& Njeru, A. (2015). Effect of Loan Repayment on Financial Performance of Deposit taking SACCOs in Mount Kenya Region. International Journal of Innovation and Applied Studies, 1238-1244.

[78]. O'Brien, J. (2005). Governing the Corporation: Regulations and Corporate Governance in an Age of Scandal and Global Markets. New Jersey: John Wiley and Sons.

[79]. Odhiambo, J. (2011). The Relationship Between Working Capital and Fiancial Performance of Deposit Taking Savings and Credit Co-operative Societies licensed by SACCO Soceities Regulatory Audhtority in Nairobu County. Nairobi: Doctoral Dissertation; University of Nairobi.

[80]. Ogol, G. O. (2011). Liquidity Risk Management in Microfinance Institutions in Kenya. Un-published MBA research paper, University of Nairobi.

[81]. Okundi, H. O. (2011). Financial challenges facing savings and credit co-operative societies in Kenya; The case of SACCOs in Nairobi. Nairobi: Phd Dissertation. University of Nairobi.

[82]. Olando, O. C., Mbewa, O. M., \& Jagongo, A. (2012). Financial Practice as a Determinant of Growth of Savings and Credit Cooperative Soceities' Wealth; A pointer to overcomming poverty challenges in Kenya and the Region). International Journal of Business and Social Science, 3(24), 204-219.

[83]. Oldfield, G. S., \& Santomero, A. M. (1995). The place of risk management in financial institutions. Wharton School, University of Pennsylvania.

[84]. Omosa, J., \& Morara, J. M. (2014). Fauilure of Good Governance in State Owned Corporations in Kenya: Towards a More Effective Parliamentary Monitoring Role. PhD Dissertation, University of Nairobi, 1-126.

[85]. Orodho, J. A. (2002). Techniques of Writing Research Proposals and Reports in Education and Social Sciences. Nairobi: Masola Publishers.

[86]. Owojori, A. A. (2009). The Role of Forensic Accounting in Solving Vexed Problem of Corporate World. European Journal of of Scientific Research, 29, 184-187.

[87]. Peterson, P. a. (2006). Analysis of financial statements. Wiley \& sons.

[88]. Polak, P. (2009). 'The Centre Holds'-From the Decentalised Treasury Towards Fully Centralised Treasury Management. Journal of Corporate Treasury Management, 3(2), 109-112.

[89]. Polak, P., Robertson, D. C., \& Lind, M. (2011). The New Role of Corporate Treasury: Emerging Trends in Response to the Financial crisis . International Research Journal of Finance and Economics, 78.

[90]. Raussand, M. (2013). Risk Assesmement; Theory, methods and application. Hoboken New Jersey: John Wiley and Sons.

[91]. Robson, C. (2002). Real World Research: A Resource for Social Scientists and Practitioners-Research (Vol. 2). Oxford: Balckwell.

[92]. Sadgrove, M. K. (2015). The complete guide to business risk management. Ashgate Publishing Ltd.

[93]. SASRA. (2013). Sacco Supervision Annual Report. Nairobi: SACCO Societies Regulatiory Authority.

[94]. SASRA. (2014). Sacco Supervision Annual Report (2013) (Deposit Taking Saccos). Nairobi: Sacco Societies Regulatory Authority.

[95]. SASRA. (2015, February 3rd). www.sasra.go.ke. Retrieved July 20th, 2015, from Sacco Societies Regulatory Authority: http//www.sasra.go.ke/index.php/regulation/licensed-saccos\#Va0akpmqqko

[96]. SASRA;. (2014). SACCO SUPERVISION ANNUAL REPORT; Deposit taking SACCO Societies . Nairobi: SACCO Societies Regulatory Authority.

[97]. Saunders, A., Cornett, M. M., \& McGraw, P. A. (2006). Financial Insitutions Management; A Risk management approach (Vol. 8). Irwin: McGraw Hill.

[98]. Schoeberg, R. (2006). Measurign the Performance of Coporate Acquisitions: An Empirical Comparison of Alternate Metrics. British Journal of Management(17), 361-370.

[99]. Shelley, L. I. (2014). Dirty Entanglements: Corruption, Crime and Terrorism. Cambridge: Cambridge University Press.

[100]. Shiller, R. J. (2012). The Subprime Solution: How Today's Global Financial crisis Happened and What to do about it. Princeton: Princetone University Press.

[101]. Simutis, R., Dilijonas, D., \& Bastina, L. (2008). Cash Demand Forecasting for ATM using Neural Networks and Support Vector Regression Algorithms. 20th EURO mini Conference. Vilinius.

[102]. Singh, M., Sandra, P., \& Kurt, S. N. (2015). Addressing Financial Reporting Complexity: Investors perspective. Journal of Accounting, 26(3), 45-46.

[103]. Sonkushre, P. K. (2012, January 21). Retrieved May 18, 2012, from www.demtruereality.comFinance\&AccountingMBA: http://www.ehow.com/about 4815874 forensic accounting

[104]. Stanik, J. M. (2013). Psychology and Law Crucial Theoretical and Applicative Problem. Chowanna, 2(37), 5-97.

[105]. Suarez, -B., Manuel, F., \& Ligham, T. (2008). "Kaizen within Kaizen teams: Continous and process improvement in a Spanish Minicipality". Assian journal on Quality, 9(1), 1-21.

[106]. The Republic of Kenya;. (2010, June 18th). Sacco Societies (Deposit-Taking Sacco Business) Regulations, 2010. Kenya Gazette No. 39, Legal Notice No.95. Nairobi, Kenya: Government of Kenya.

[107]. Toshiba, S., Singh, S. K., \& Kashayap, A. K. (2013). Application of Queing Theory for the improvement of Bank Service. SARCIRAJ International Conference (pp. 44-47). Pune, India: Chhatrapati Shivaji Institute of Technology.

[108]. Trochimm, W. A., \& Land, D. A. (1982). Designing Designs for Research. London: Wiley Publishers.

[109]. Van Greuning, H., \& Brajovic, S. (2003). Analyzing and Managing Banking Risks; Aframework for Assesing Corporate Governance and Financial Risks (2nd ed.). Washington DC, USA: The International Bank for Reconstruction and Development; The World Bank.

[110]. Vose, D. (2008). Risk Analysis: a quantitative guide. John Wiley \& Sons.

[111]. Wanjiru, L. K. (2011). Strategic Responses of Equity Bank to Fraud related risks. Unpublished MBA Research, Kenyatta University.

[112]. Wanyama, F. O. (2009). Surviving Liberalization; The Coperative movement in Kenya. ILO.

[113]. Wanyama, F. O., Develtere, P., \& Ignace, P. (2008). Ecnountering the Evidence;Co-operatives and Poverty Reduction in Africa. Journal of Co-operative studies, 16-27.

[114]. Wanyama, F., Develtere , P., \& Pollet , I. (2009). "Reinventing the wheel? African Co-operative in liberalized economic environment". Annals of Public and Co-operative Economics, 80(3), 361-392. 
[115]. Waweru, K. M. (2011, July 14). An Investigation into the Cash balance management challenges in Savings and Credit Co-operative Societies (SACCOs) in Nakuru County, Kenya. Journal of Research in International Business and Management.

[116]. World Council of Credit Unions (WOCCU). (2014). Statistical Report as at December 2014. Washington DC: WOCCU.

[117]. Yoshinda, F. (2012). The Mechanism of Modern Capitalism and Environmental Destruction. Japan: Japan.

[118]. Zenious, S. A., \& Ziemba, W. T. (Eds.). (2007). Handbook of Asset and Liability Management Applications and case studies (Vol. 2). Elsevier.

[119]. Ziglidopoulos, S. C. (2005). The Escalation of Corruption in Organization in R. J. Burke \& C. L. Cooper. Research Companion to Corruption, 14-27.

[120]. Zikmund, W. G., Babin, B. J., Carr, J. C., \& Griffin, M. (2012). Business Research Methods (9th ed.). Mason: Cengage.

[121]. Zyglidopoulos, S. C. (2009). The Escalation of Corruption in R. J. Burke and C. L Cooper. Research Companion to Corruption in Organization, 14-27. 